\title{
The Effectiveness Of The Implementation Of Independent Community Empowerment Programs In Bone District
}

\author{
M. Awaluddin A, Muhammad Luthfi Siraj, Yusriadi Yusriadi
}

\begin{abstract}
The implementation in Bone Regency from the aspect of community development, direct community assistance, capacity building for the government, local actors, management assistance, and program development showed effective results. Implementation has been carried out by the organizers well in carrying out development programs starting with the construction of road infrastructure, irrigation, lending business funds to the community. The program provides changes to the economy and social life of the city. The implementation of this program has several obstacles, such as the community lacking understanding of the aims and objectives of the program, the lack of responsibility of some communities in returning the revolving funds that have given.
\end{abstract}

Index Terms: Effectiveness, Policy, National Program, Indonesia

\section{Introduction}

The implementation of development oriented to meeting community needs requires the role of government organizations, empowerment, and innovation through community service. The part of government organizations in addition to achieving the target of increasing community income also participates in or participates directly in decision making, and implementation of activities becomes a habit for them, while the level of participation in development is still limited, for example, physical partnership without a broad role from planning to evaluation. These changes will require changes in government organizations, especially traditional paternalistic patterns, to behavior patterns of government oriented to public services. The government has pursued the community empowerment approach through various sect oral and regional developments. Through the Implementation of the National Independent Community Development Program, it expected that harmonization of fundamental principles, methods, strategies, mechanisms, and procedures for development based on community empowerment could occur so that the process of improving community welfare can run more effectively and efficiently. The government's efforts to accelerate the reduction of poverty-based participation are expected to create a social strengthening process that can lead needy people to prosperous communities (Sumodiningrat, 2009). Through this policy, the poverty reduction mechanism is formulated by involving community elements, starting from the planning, implementation, monitoring, and evaluation phases. The participatory development process, critical awareness, and community independence can develop so that they do not act as objects but as subjects in poverty reduction efforts.

- M. Awaluddin A, Sekolah Tinggi Ilmu Administrasi Prima, awalstiaprimabone@gmail.com

- Muhammad Luthfi Siraj, Universitas Negeri Makassar, muhammadluthfisiraj@gmail.com

- Yusriadi Yusriadi, Sekolah Tinggi Ilmu Hukum Pengayoman, yusriadi.yusriadi@uqconnect.edu.au
The purpose of empowerment is the situation or things that want to be achieved by a social change. Communities who are empowered, have the power or have the knowledge, and ability to fulfill their needs both physically, economically and socially, such as having self-confidence, being able to express aspirations, have a livelihood, participate in social activities, and be independent in carrying out tasks his life (Suharto, 2005). The implementation of poverty alleviation through national programs is one form of public policy government instruments to alleviate poverty through the empowerment of independent communities carried out based on the fundamental principles established by all the laws of poverty reduction through the empowerment of autonomous cities. This program implemented through harmonization and development of systems and program mechanisms and procedures, provision of assistance, and stimulant funding to encourage community initiatives and innovations in sustainable poverty reduction efforts. In the 2007 guidebook for implementing the program, it explained that to reduce poverty through increasing community participation in the development process, increasing the capacity of local government in the provision of public services, and increasing the size of local community-based institutions. One of the processes in developing the capacity of the apparatus is education and training activities (Yusriadi, Sahid, Amirullah, Azis, \& Rachman, 2019). The participatory development program that prioritizes the community as the main actor of development. Fundamental values are believed to be able to encourage the realization of program objectives. Stated that the program principles include 1) relying on human development, 2) autonomy, 3) decentralization, 4) oriented to the poor, 5) participation, 6) gender equality and justice, 7) democratic, 8) transparency and accountability, 9) priority, 10) sustainability (Suryadi, 2006). This program is expected to increase the synergy between the community and the local government to streamline poverty reduction efforts. Bone District is one of the target areas of the program that has a homogeneous society, some people have a lot of limitations in working conditions such as a group of citizens who are still unemployed, and some have jobs as laborers, and as motorcycle taxi drivers. The income of residents in Bone Regency has an irregular income, and this does not help their welfare. By looking at the condition of the village community in Bone Regency, the national program for empowering 
independent communities is one of the efforts of the Bone District government policy to develop the economy and build infrastructure in the village.

\section{Research Method}

This type of research is qualitative, with a descriptive approach which considers the observed symptoms related to the Implementation of the National Independent Community Empowerment Program in Bone Regency. This study focuses on aspects of community development, direct community assistance, government capacity building, local actors, management assistance, and program development. The research uses primary data sources with interview methods and secondary data in the form of observations as supporting research data. The data collection technique was carried out by an intensive view of the Implementation of the National Independent Community Empowerment Program in Bone Regency, an interview technique as the primary media in the study. Data analysis used interactive models, namely condensation of data, presentation of data, and conclusions or verification (Miles, Huberman, \& Saldana, 2014).

\section{Result and Discussion}

One of the results of the reforms was the birth of regional autonomy which the government and the people hoped for in the region (Yusriadi, 2018c). The implementation of the National Independent Community Empowerment Program in Bone Regency has been running effectively, the application of its programs has been established to provide management consultants, quality control, evaluation, and program development which have roles in improving the economic and social life of the people in Bone Regency. The implementation of the program considered useful because it supported by good collaboration between the implementers of the subdistrict apparatus and the communities involved as implementers and the community as recipients of the program. Looking at the implementation of the program in Bone Regency from the aspect of community development, every year there is an increase in terms of the number and quality of communities that can be empowered, improvements in facilities and infrastructure, and the most important thing is the continued interest from the city in appreciating this program. Data from the interviews illustrate the implementation of the National Independent Community Empowerment Program in Bone District that has had a significant impact on people's lives. Following the results of interviews with informants saying the program has provided changes in people's lives, especially changes in the economy, no longer being unemployed. They can now work by establishing a business for the capital assistance provided by the program. The community wants reforms to follow by fundamental changes in the design of people's lives, related to political, social, economic, and cultural dimensions (Yusriadi, 2018b) The community actively and consciously maintains, maintains, maintains all the infrastructure and facilities that have built. In the aspect of direct community assistance, the program has been able to improve access to a prosperous life for the community and community groups to carry out production processes and business opportunities, through providing capital assistance and developing human resources. In the aspect of capacity building for government and local actors, the program can run quite effectively because participatory planning activities can accommodate all the expectations and desires of the target group of the program. Besides that, along with the village head, and the community involved in the program can carry out their duties and functions effectively in mobilizing and engaging all levels of the city to make program planning and program implementation. In the aspect of program management and development assistance, the program can run quite effectively because it has a reasonably skilled management team and can develop the application under the needs and desires of the community as program targets. One informant revealed the effectiveness of the program implementation in supporting development showed that the program could run effectively because of the role of facilitators who were able to help the community in identifying various environmental potentials that could manage as productive businesses. The era of globalization has had an impact on various aspects of human life, on the one hand bringing climate more open to filling and completing multiple things, on the other hand, the situation of competition is getting tighter and tighter. One of the reform agenda is to create a clean government, and free from the practices of corruption, collusion, and nepotism (Yusriadi \& Farida, 2019). Furthermore, some informants also said that the participation and capacity of the population in planning, implementing, preserving and developing the development results that have achieved gives a significant value so that from year to year the program can continue to show progress and increase the amount of the budget. Some of the roles of facilitators in community development are 1) facilitator or catalyst, namely they must stay between target groups accompanying group development processes, helping to solve problems and participate in determining alternative solutions. 2) as a trainer and educator, namely finding and channeling information and experience from outside into the group through various teaching and learning methods; 3 ) capital fertilizers, namely encouraging efforts to save, save, productive businesses; 4) organize stimulant projects to promote the independence of the target group. However, the implementation of this program opened a gap in action from program actors who seemed not transparent in managing activities and budgets. One of the informants revealed that the application of budget activities and uses was not seamless to the community due to the absence of information space in the form of formal meetings or in the way of publications which explained in full about the flow of annual budget use. An effective organization must have advanced planning for human resource demand in the future and how to fulfill that demand through various supply scenarios - barring the existence of advanced human resource development planning (Yusriadi, 2018a). Financial audits are only carried out by authorized government agencies and do not involve the community as a whole. It cannot deny that the previous programs often produced unfavorable conditions, this, in fact, encouraged a shift in the behavior of people who were not independent, so that people tended to act on the assistance of outside parties to overcome various problems faced - the lack of responsibility of some communities in returning the revolving funds from the program. Many poor people feel pressured into economic conditions so that they do whatever they can to get funds but ultimately cannot return the funds. Even though the program fund is a grant that does not need to return to the government, the government hopes that the community can develop the funds as a form of community empowerment to combat poverty jointly. 


\section{Conclusion}

Based on the results of research on the implementation of the program in Bone Regency, it can conclude that the implementation of the National Independent Community Empowerment Program seen from the aspects of community development, direct community assistance, capacity building for government, local actors, management assistance, and active program development. Obstacles in the implementation of the program are that the community does not understand the aims and objectives of the application being implemented and the lack of responsibility for part of the population in revolving refunds. Based on these conclusions, there are some suggestions as follows: the program should have an evaluation mechanism that involves the community so that the community can know the extent of the successes and disadvantages faced. As well as opening space and open access to the community in managing aid funds, so as not to cause mutual suspicion between managers and the community.

\section{References}

[1] Miles, M. ., Huberman, A. ., \& Saldana, J. (2014). Qualitative Data Analysis, A Methods Sourcebook (3rd ed.). USA: Sage Publications.

[2] Suharto, E. (2005). Membangun Masyarakat Memberdayakan Rakyat. Bandung: PT. Refika Aditama.

[3] Sumodiningrat, G. (2009). Pemberdayaan Masyarakat dan JPS. Jakarta: PT Gramedia.

[4] Suryadi, S. (2006). Pemberdayaan Masyarakat Untuk Membangun Kemitraan Pengelolaan Taman Nasional. Sinergi: Jurnal Manajemen Kolaborasi. LATIN, 1(2), 114.

[5] Yusriadi. (2018a). Bureaucratic Reform Barriers: A Case Study on the One Stop-Integrated Service Office in Bone Regency. Jurnal Kebijakan Dan Administrasi Publik, 22(2), 146-154. Retrieved from https://jurnal.ugm.ac.id/jkap/article/view/34536

[6] Yusriadi. (2018b). Reformasi Birokrasi Indonesia: Peluang dan Hambatan. Jurnal Administrasi Publik (Public Administration Journal), 8(2), 178-185. Retrieved from

https://ojs.uma.ac.id/index.php/adminpublik/article/view/1 824

[7] Yusriadi. (2018c). Tantangan Reformasi Birokrasi Berbasis E-Procurement di Indonesia. Publikauma: Jurnal Administrasi Publik Universitas Medan Area, 6(2). Retrieved from https://ojs.uma.ac.id/index.php/publikauma/article/view/1 635

[8] Yusriadi, \& Farida, U. (2019). Bureaucracy Performance in Public Services in Indonesia. Jurnal Administrare: Jurnal Pemikiran Ilmiah Dan Pendidikan Administrasi Perkantoran, 6(1), 17-24. Retrieved from https://ojs.unm.ac.id/administrare/article/view/9434

[9] Yusriadi, Sahid, A., Amirullah, I., Azis, A., \& Rachman, A. A. (2019). Bureaucratic Reform to the Human Resouces: A Case Study on the One-Stop Integrated Service. The Journal of Social Sciences Research. Retrieved from https://arpgweb.com/pdf-files/jssr5(1)61-66.pdf 